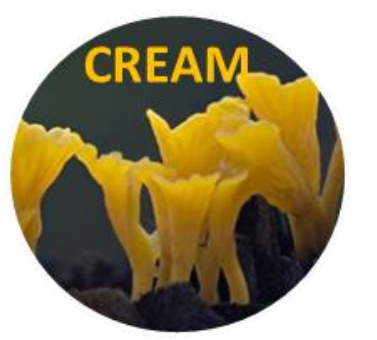

Current Research in Environmental \& Applied Mycology 5 (4): 307-321(2015) ISSN 2229-2225

$\underline{\text { www.creamjournal.org }}$

Article

CREAM

Copyright $@ 2015$

Doi 10.5943/cream/5/4/2

\title{
Wild Mushrooms from Tanzania: Characterization and their Importance to the Rural Communities
}

\author{
Chelela BL ${ }^{1}$, Chacha $\mathrm{M}^{1}$ and Matemu $\mathrm{A}^{2 *}$ \\ ${ }^{1}$ Department of Biodiversity and Ecosystems Management, School of Life Sciences and Bioengineering, Nelson Mandela \\ African Institution of Science and Technology, P. O. Box 447, Arusha, Tanzania. Email: lucab@nm-aist.ac.tz \\ ${ }^{2}$ Department of Food and Nutritional Sciences, School of Life Sciences and Bioengineering, Nelson Mandela African \\ Institution of Science and Technology, P. O. Box 447, Arusha, Tanzania. Email: athanasia.matemu@nm-aist.ac.tz
}

Chelela BL, Chacha M and Matemu A 2015 - Wild mushrooms from Tanzania: Characterization and importance to the rural communities. Current Research in Environmental \& Applied Mycology 5(4), 307-321, Doi 10.5943/cream/5/4/2

\begin{abstract}
Tanzania has a rich diversity of wild mushrooms, both edible and inedible which are used as food and medicinal resources. Despite of their nutritional and medicinal importance, few studies have been done on their characterization. This study was carried out to characterize some wild mushrooms collected from Iringa and Njombe regions in the Southern Highlands of Tanzania in January, 2014. A semi-structured questionnaire was used to collect information on edibility, local (vernacular) names, indigenous knowledge and its importance to the rural communities. Indigenous characterization was done in the field, based on the key features (colour, shape and association with other plants), and photographs were taken. Conventional characterization was done using different key references, manuals, monographs and databases. Only five wild mushrooms were reported to be edible on the basis of indigenous information. Local names were found to be very important distinguishing factor between edible and poisonous mushrooms. On the other hand, conventional characterization revealed 7 edible species (Russulaceae-4 and Cantharelaceae-3), 11 inedible species (Boletaceae-4, Polyporaceae3, Russulaceae-2, Suillaceae-1 and Agaricaceae-1), 2 deadly poisonous (both Amanitaceae) and 4 of unknown edibility (Russulaceae-2, Suillaceae-1 and Boletaceae-1). Most of the species of wild mushrooms were found to share the same ecological habitat. Only edible wild mushrooms were reported to be of importance as opposed to inedible species. Mushroom characterization proved to be a crucial distinctive criterion for distinguishing between edible and inedible species. Taxonomic studies have been shown to be important for accurate classification of wild mushrooms, thus preventing the waste of some edible species and human deaths from the consumption of poisonous ones.
\end{abstract}

Key words - Benna - conventional - characterization - Hehe - indigenous - Tanzania - wild mushrooms

\section{Introduction}

Tanzania contains a plentiful supply of unidentified wild mushroom species that are considered to be inedible without scientific proof. The shortage of taxonomic studies on wild mushroom species limits their further exploitation. Wild mushrooms include edible mycorrhizal, symbiotic, and poisonous mushrooms collected only from the wild (Feeney et al. 2014). Mushrooms are known as an important resource providing food and nutritional security, ingredients for folk medicine and extra 
income to the rural communities (Chelela et al. 2014d, Tibuhwa 2012). Recently, there has been increasing interest in mushrooms utilization worldwide, because of their taste, health promoting nutrients and medicinal properties (Kim et al. 2008, Rana 2005, Wong \& Chye 2009, Chang \& Miles 1992, Ramírez-Anguiano et al. 2007). The estimated number of mushroom species on earth is about 140,000, but only 14,000 (10\%) are known (Hawksworth 2004). In Tanzania, over 60 edible mushroom species have been identified (Bloesch \& Mbago 2008, Härkönen et al. 2003), mostly collected from the wild during the rainy season.

Identification of wild mushrooms requires a basic knowledge of the structure of the fungi and of the way in which they live (Feeney et al. 2014). For many generations, indigenous characterization has been used to distinguish informally between edible and poisonous mushroom species. Most of the local communities in Tanzania rely on indigenous characterization, which is the most common cause of mushrooms' misidentification. It is particularly disconcerting to find such an unreliable method employed in the midst of highly advanced technologies. Indigenous characterization is commonly used for mushrooms that are easy to identify. Whilst certain mushrooms are easy to identify, however many are not, since there is a number of similar features which cannot be easily characterized. Therefore, to avoid any unpleasant experiences, especially when identifying mushroom for the purpose of determining edibility, experts should always be consulted.

Taxonomic studies appear in the secondary school curriculum of students in developed countries, but this is not the case in developing countries (Härkönen et al. 1995). Very few taxonomic studies have been conducted in Tanzania, with informal methods commonly used. Therefore, proper classification will overcome ambiguities which cannot be resolved by indigenous characterization. According to Tibuhwa et al. (2010), identity characters of the mushrooms can be seen with the naked eye, hand lenses, microscopes and more recently by molecular techniques.

Studies on edible mushrooms in Miombo woodland have been also reported in other regions (Buyck 2012, Buyck et al. 2012, Harkonen et al. 1993, Härkönen et al. 1994, Härkönen et al. 1995, Härkönen et al. 1994, Härkönen et al. 2003, Tibuhwa \& Buyck 2008, Tibuhwa 2012a, Tibuhwa et al. 2012). However, studies on the characterization of wild mushrooms in the Southern Highlands of Tanzania are very limited. The importance of folk and taxonomic characterization of wild mushrooms, in addition to their contribution to the rural communities were evaluated.

\section{Materials \& Methods}

\section{Study area}

The study was conducted in Nyombo, Ikuna and Matiganjola villages (Njombe region) and Kikombo, Matanana and Nyololo villages (Iringa region) in the Southern Highlands of Tanzania. The study area is located at $9^{\circ} 20^{\prime} 0^{\prime} \prime \mathrm{S}$ and $34^{\circ} 46^{\prime} 0^{\prime \prime} \mathrm{E}$ (Njombe) and $7^{\circ} 46^{\prime} 0^{\prime \prime} \mathrm{S}$ and $35^{\circ} 42^{\prime} 0^{\prime \prime} \mathrm{E}$ (Iringa) with annual average rainfall of 1160 and $661 \mathrm{~mm}$ respectively. Availability and higher consumption of wild mushrooms among the communities in the regions were amongst the selection criteria. The study area consists of mixed forest where the Miombo woodland with Brachystegia and Uapaca spp. are dominant, whereas wild mushrooms are plentiful during the rainy seasons.

\section{Questionnaire survey}

A survey using semi-structured questionnaires as well as a focused group discussion was used to collect information on indigenous (folk) taxonomy, local names and edibility of wild mushrooms. A total of 120 respondents from six villages ( $n=20$; per village), mostly mushroom hunters, collectors, retailers and consumers were involved.

\section{Wild mushroom collection}

Wild mushrooms were collected in the Iringa and Njombe regions in January, 2014. According to Verbeken and Buyck (2002), several Miombo woodland species have a restricted fruiting period and occur during only part of the season. Photographs of mushrooms were taken in situ; they were morphologically characterized before picking and their substrate recorded (Tibuhwa 2011a, Tibuhwa 
2011b, Tibuhwa \& Kivaisi 2010). The fruiting bodies were preserved in ethanol for further characterization.

\section{Characterization of wild mushrooms}

Field observation and indigenous characterization of the wild mushrooms was done based on morphological (macro) features. Macro fungi were characterized using coloured field guide books, monographs and published work (Härkönen et al. 1995, Tibuhwa, 2012, Tibuhwa \& Kivaisi 2010, Tibuhwa 2011a; Tibuhwa, 2011b) as well as databases. Conventional characterization was based on the features such as cap colour, size, and shape, the outer surface of the fruiting body, cap surface texture, gills/tubes and latex, edibility, ecological and host substrate specificity. The macro-fungi nomenclature was according to Kirk \& Ansell (1992) and CABI bioscience databases (CABI, 2015). Scientific names were also recognized by the 'Index fungorum'.

\section{Data analysis}

Collected information from the survey data were descriptively evaluated and summarized in tabular form, as shown in Table 1.

\section{Results}

\section{Indigenous characterization}

Indigenous (folk) characterization of wild mushrooms collected in the Njombe and Iringa regions has revealed 5 edible and 17 inedible species (Table 1). Simple morphological forms such as colour, shape, and association with other plants were the key features for indigenous characterization. Local names were also found to be an important element when distinguishing edible from poisonous species. Local names of the edible species were Wisimba (L. edulis), Wifimi/Unyakuwemba (L. densifolius), Unyambete/Unyamikwe ( $R$. roseovelata), Wagingili ( $R$. cellulata) and Wipatwe $(C$. tomentosus). On the other hand, not all of the inedible species were found to bear a local name as they were considered valueless by the communities since they were not known to be consumed (Table 1). This study justifies the importance of indigenous characterization as a preliminary method for the identification of wild mushrooms, based on their edibility in the rural communities. Likewise, conventional characterization is of paramount as the indigenous method cannot efficiently, for instance, differentiate closely similar species of which one may be poisonous.

\section{Conventional characterization}

Conventional characterization of the wild mushrooms was performed by observing different features including cap colour, cap surface texture, gills/tubes and latex, ecological classification, host substrate specificity and edibility (Table 1). Other field characters, such as spore print, odour and taste, cup edge curliness, fruiting body fleshiness, and developmental stages and forms were also noted. Through conventional characterization, 7 species of wild mushrooms were found to be edible (Fig. 1), 11 inedible (Fig. 2), 2 deadly poisonous (Fig. 3), and 4 of unknown edibility (Fig. 4). Conversely, species of Afrocantharellus symoensii and Cantharellus densifolius which were previously categorized as inedible (by the indigenous method) were reported to be edible (Table 1). Other edible species of $L$. edulis, $L$. densifolius, $C$. tomentosus, $R$. roseovelata and $R$. cellulata were the same as previously characterized by the indigenous method. These species were mainly from Russulaceae and Cantharelaceae families. Furthermore, 2 species of Amanita muscaria and Amanita phalloides were also further characterized as deadly poisonous; they had been previously reported to be inedible (by the indigenous method) which proves beyond doubt that they are unfit for human consumption (Fig. 3). Moreover, 4 other species of unknown edibility which were also indigenously considered as inedible, belong to the Russulaceae-2, Boletaceae-1 and Suillaceae-1 families (Fig. 4). Inedible wild mushrooms were found in the Boletaceae-4, Polyporaceae-3, Russulaceae-2, Agaricaceae-1 and Suillaceae-1 families. Additionally, the taxonomy of most of the wild mushrooms was recorded. 

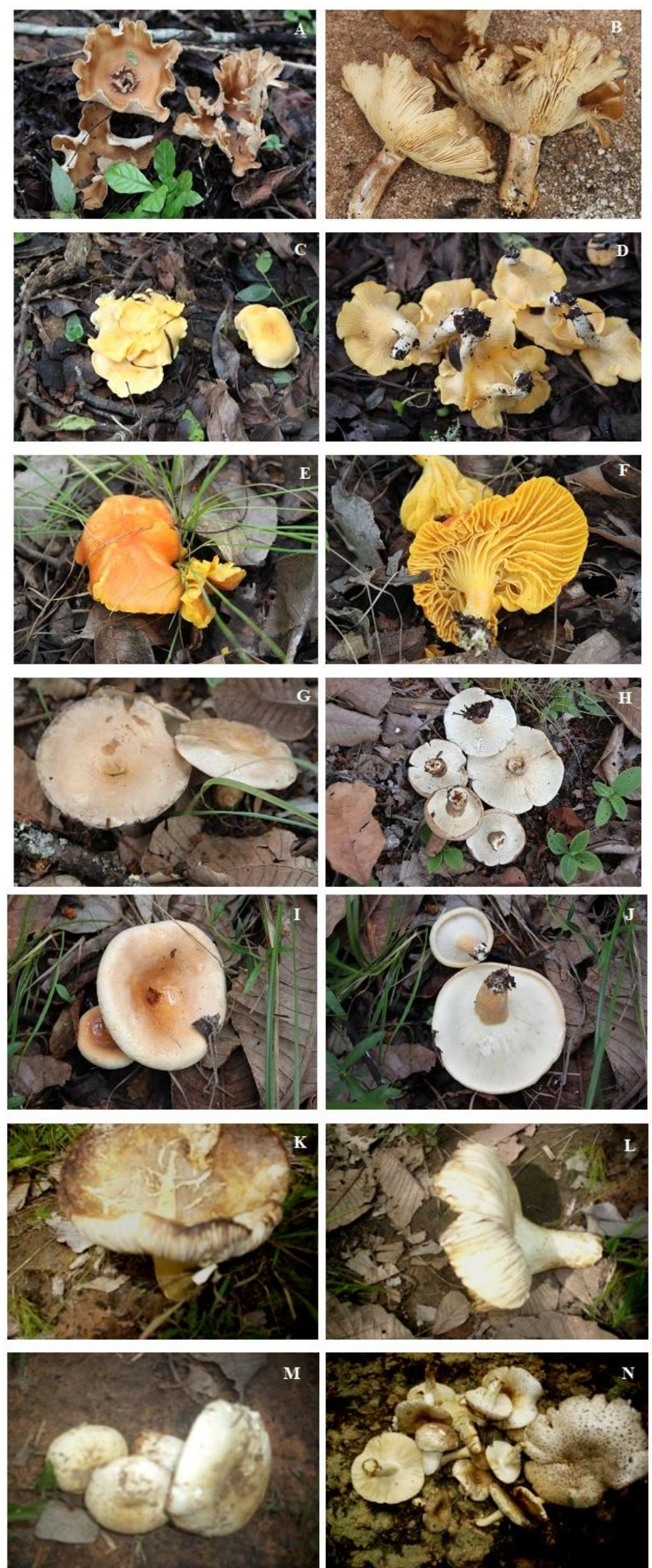

Fig. 1 - Edible wild mushrooms in Cantharellaceae-3, and Russulaceae-4 families. (a) A-B: Cantharellus tomentosus; C-D: Cantharellus densifolius; E-F: Afrocantharellus symoensii; G-H: Russula cellulata; (b) I-J: Lactarius densifolius; K-L: Lactarius edulis and M-N: Russula roseovelata. 

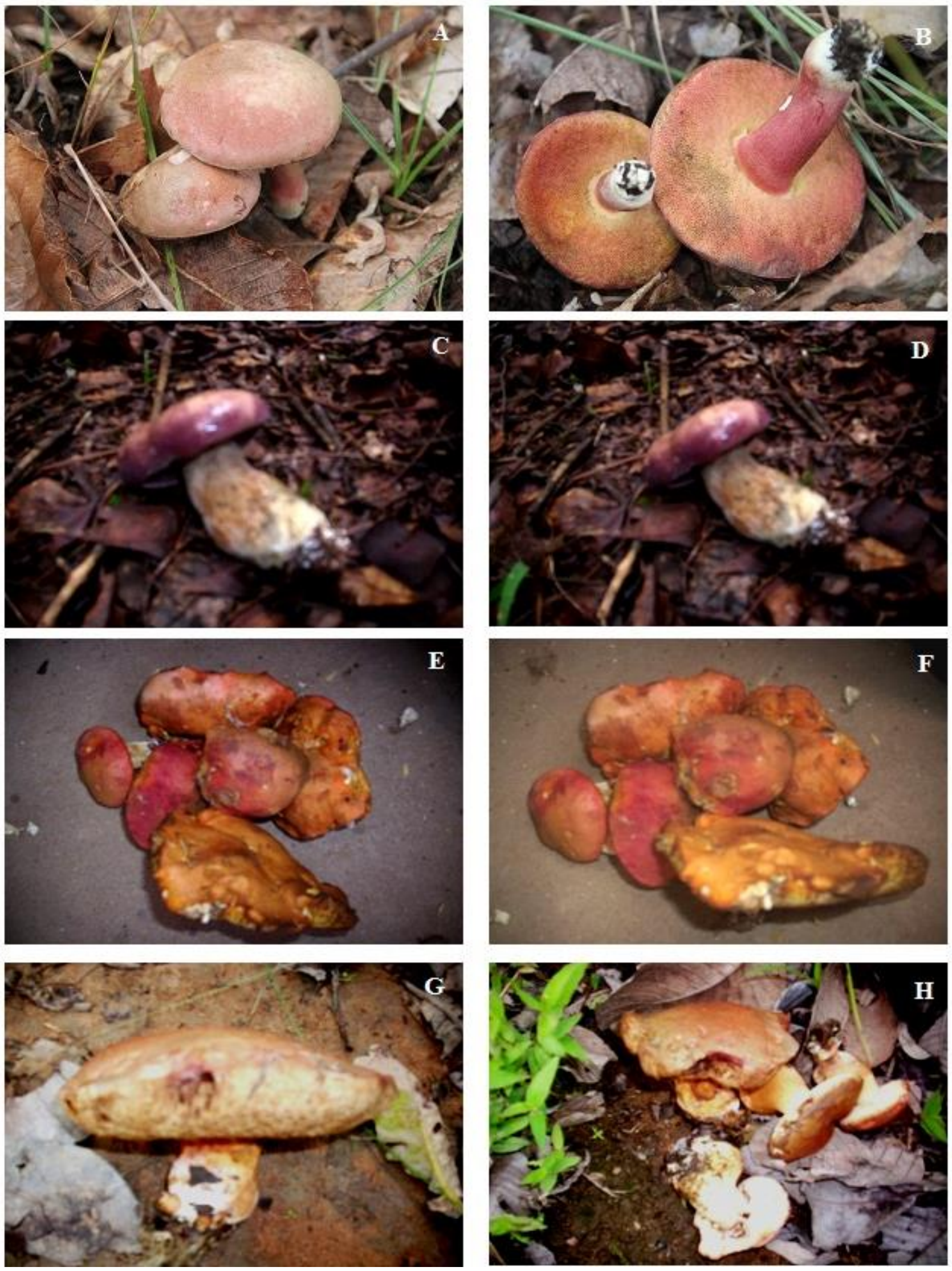

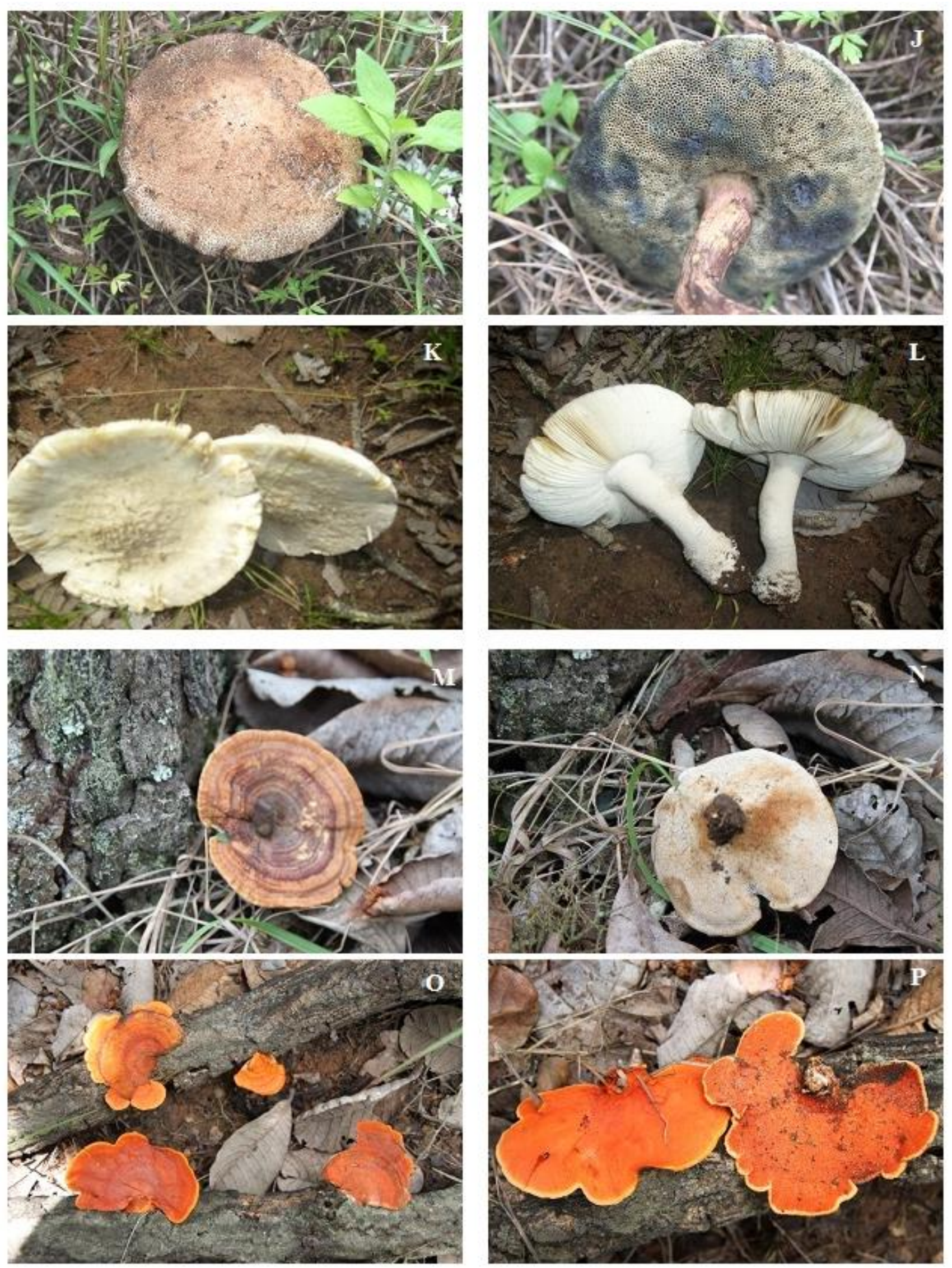

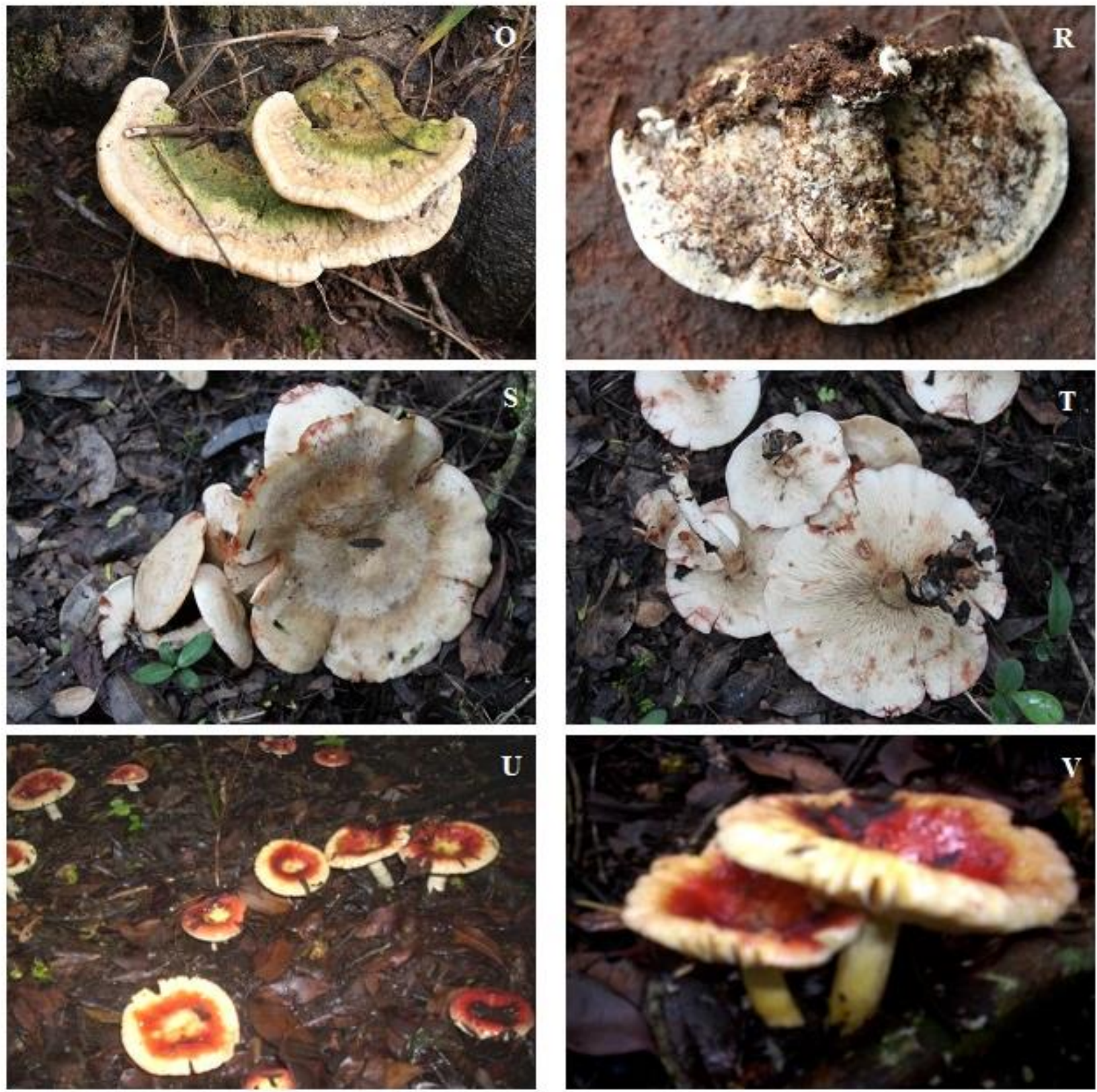

Fig. 2 - Inedible wild mushrooms in Boletaceae-4, Suillaceae-1, Agaricaceae-1, Poplyporaceae-3 and Russulaceae-2 families. (a) A-B: Boletus spp-1.; C-D: Boletus spp-3.; E-F: Boletus spectabilissimus; G-H: Boletus spp-4; (b) I-J: Suilluis tomentosus; K-L: Chlorophyllum molybdites; M-N: Microporus xanthopanus; (c) O-P: Pycnoporus sanguineus; Q-R: Trametes menziesii; S-T: Lactarius denigricans and U-V: Russula kivuensis.

Most of the wild mushrooms species were found to share the same ecological, host or substrate and gills/tubes and latex characteristics, with some exceptions in cap surface texture, colour, shape and size (Table 1). Specifically, most of the wild mushroom species in the families of Russulaceae, Cantharelaceae, Polyporaceae, Boletaceae and Amanitaceae were shared the same habitat and ecological characteristics. This is due to the characteristics of the area (Southern Highlands) and nature of the habitat (Miombo woodland with Brachystegia and Uapaca spp.), where a particular species of mushroom grows. 
Generally, some of the wild mushroom species indigenously characterized as either edible, inedible or with unknown edibility were from one family of Russulaceae indicating that conventional conventional characterization is necessary to avoid misidentification which may lead to fatalities. General description and identification marks of the wild mushroom species collected from the Njombe and Iringa regions are as described in Table 1 and Fig. 1- 4.

It was found that local names were very important in indigenous characterization since the edibility of mushrooms could be easily established on the basis of their local names (Table 1). Similarly, vernacular names of locally edible fungi were also reported in other studies (Chelela et al. 2014d, van Dijik et al. 2003, Härkönen et al. 1995, Tibuhwa 2012a). Vernacular names, however, play no role in scientific classification (Harkonen 2002).

Knowing the scientific name of a fungus provides a good indication of its edibility (Boa 2004). Russulaceae and Cantharelaceae were the main families of edible wild mushrooms reported in this study. According to Tibuhwa, (2013), Russulaceae and Cantharelaceae, among other families, were commonly consumed and sold in the local markets in different places in Tanzania. Likewise, some edible Cantharellus species have also been reported from the tropical African Savannah woodlands (Buyck 2012, Tibuhwa et al. 2012). In our previous study, Cantharellus, Lactarius, Termitomyces, Amanita, Russula, Afrocantharellus and Macrolepiota were the genera of wild edible mushrooms reported to be consumed by the Hehe and Benna communities (Chelela et al. 2014d). Likewise, edible species of Cantharellus, Russula, Auricularia and Termitomycetes were reported in Kenya (Feeney et al. 2014) and Sudan (Abdalla et al. 2014). Furthermore, the most commonly used species were those of the genera Cantharellus, Lactarius, Russula, Termitomyces and Amanita (Härkönen et al. 1994, Tibuhwa 2013). Generally, the ectomycorrhizal fungi in tropical Africa are represented by Cantharellaceae, Russulaceae, Boletales and Amanitaceae (Tibuhwa \& Buyck 2008, Verbeken \& Buyck 2002). It is evident that most of the Lactarius spp., Russula and most of the ectomycorrhizal groups have been collected either in open (Miombo, Uapaca) woodland or in dense forest types but rarely in both (Verbeken \& Buyck 2002). Besides, the Southern Highlands habitat is characterized by Miombo woodland with Brachystegia and Uapaca spp. Furthermore, the variety of edible species was reported to be larger in Miombo woodlands as compared to mountainous areas (Härkönen et al. 1994). Herein, 7 species were indigenously identified as edible and the rest were inedible species of wild mushrooms (Table 1).

Wild edible mushrooms are accepted and valued as a source of food by most of the rural mushroom hunting communities in Tanzania (Chelela et al. 2014d, van Dijik et al. 2003, Tibuhwa 2013, Tibuhwa 2012a). Some studies have also concentrated on wild mushrooms as source of food in Tanzania (Harkonen 2002, Yongabi et al. 2004, Tibuhwa 2012). According to Harkonen (2002) and van Dijik et al. (2003) some communities in Tanzania and Cameroon consider mushrooms to be similar to meat. Wild mushrooms can also offer seasonal self-employment to mushroom hunters, collectors and retailers during peak seasons (Chelela et al. 2014d).

Conversely, the 11 inedible wild mushroom species were mainly from the Russulaceae, Boletaceae, Polyporaceae, Agaricaceae, and Suillaceae families as shown in Fig. 2. Regardless of their lack of value to the rural communities, preliminary studies have shown that some of the inedible wild species can be a potential source of bioactive compounds with medicinal properties (Chelela et al. 2014a, Chelela et al. 2014b, Chelela et al. 2014c). Generally, studies on the medicinal properties of wild inedible mushrooms in Tanzania are very scarce, regardless of their therapeutic potential and other biological properties. Available information indicates that no documentation of inedible wild mushrooms from the Southern Highlands of Tanzania has been done. Therefore, this study is the first to document the presence of inedible wild mushroom species from the Southern Highlands of Tanzania. Inedible species can further expand the medicinal applications of mushrooms to the human population, making them valuable supplement to the few edible species already studied. 
Table 1 Indigenous and conventional characterization of wild mushrooms from the Southern Highlands of Tanzania

\begin{tabular}{|c|c|c|c|c|c|c|c|c|c|c|}
\hline Sn & $\begin{array}{l}\text { Wild Mushrooms } \\
\text { (scientific name) }\end{array}$ & Family name & $\begin{array}{l}\text { Vernacular } \\
\text { /local names } \\
\text { (Bennal } \\
\text { Hehe) }\end{array}$ & $\begin{array}{l}\text { Cap } \\
\text { colour }\end{array}$ & $\begin{array}{l}\text { Ecological } \\
\text { classification }\end{array}$ & $\begin{array}{l}\text { Host or } \\
\text { substrate }\end{array}$ & $\begin{array}{l}\text { Cap } \\
\text { surface } \\
\text { texture }\end{array}$ & $\begin{array}{l}\text { Folk } \\
\text { taxonomy } \\
\text { (Edibility) }\end{array}$ & $\begin{array}{l}\text { Taxonomic } \\
\text { classification } \\
\text { (Edibility) }\end{array}$ & $\begin{array}{l}\text { Gills/tubes } \\
\text { and latex }\end{array}$ \\
\hline 1 & Lactarius spp-1 & Russulaceae & Ngavemba & Yellow & $\begin{array}{l}\text { Miombo } \\
\text { woodlands }\end{array}$ & Mycorrhizal & Smooth & Inedible & Not known* & $\begin{array}{l}\text { Gills with } \\
\text { white latex } \\
\text { when injured }\end{array}$ \\
\hline 2 & $\begin{array}{l}\text { Lactarius } \\
\text { gymnocarpoides }\end{array}$ & Russulaceae & Ngavemba & Orange & $\begin{array}{l}\text { Miombo } \\
\text { woodlands }\end{array}$ & Mycorrhizal & Rough & Inedible & Not known* & $\begin{array}{l}\text { Gills with } \\
\text { white latex } \\
\text { when injured }\end{array}$ \\
\hline 3 & $\begin{array}{l}\text { Lactarius } \\
\text { densifolius }\end{array}$ & Russulaceae & $\begin{array}{l}\text { Wifimi/Unyaku } \\
\text { wemba }\end{array}$ & Pale brown & $\begin{array}{l}\text { Miombo } \\
\text { woodlands }\end{array}$ & Mycorrhizal & Smooth & Inedible\# & Edible* & $\begin{array}{l}\text { Gills with } \\
\text { white latex } \\
\text { when injured }\end{array}$ \\
\hline 3 & Lactarius edulis & Russulaceae & Wisimba & $\begin{array}{l}\text { Whitish } \\
\text { brown }\end{array}$ & $\begin{array}{l}\text { Miombo } \\
\text { woodlands }\end{array}$ & Mycorrhizal & $\begin{array}{l}\text { Rough with } \\
\text { cracks }\end{array}$ & Edible & Edible & Gills \\
\hline 4 & $\begin{array}{l}\text { Lactarius } \\
\text { denigricans }\end{array}$ & Russulaceae & Not known & White & $\begin{array}{l}\text { Miombo } \\
\text { woodlands }\end{array}$ & Mycorrhizal & Smooth & Inedible & Inedible & Gills \\
\hline 5 & Russula kivuensis & Russulaceae & Manyaluhano & $\begin{array}{l}\text { Red and } \\
\text { white } \\
\text { striations }\end{array}$ & $\begin{array}{l}\text { Miombo } \\
\text { woodlands }\end{array}$ & Mycorrhizal & Smooth & Inedible & Inedible & Gills \\
\hline 6 & $\begin{array}{l}\text { Russula } \\
\text { roseovelata }\end{array}$ & Russulaceae & $\begin{array}{l}\text { Unyambetel } \\
\text { Unyamikwe }\end{array}$ & $\begin{array}{l}\text { White } \\
\text { brown }\end{array}$ & $\begin{array}{l}\text { Miombo } \\
\text { woodlands }\end{array}$ & Mycorrhizal & $\begin{array}{l}\text { Rough with } \\
\text { brown spots }\end{array}$ & Inedible & $\begin{array}{l}\text { Edible after } \\
\text { Parboiling* }\end{array}$ & Gills \\
\hline 7 & Russula cellulata & Russulaceae & Wagingili & Pale brown & $\begin{array}{l}\text { Miombo } \\
\text { woodlands }\end{array}$ & Mycorrhizal & Smooth & Edible & Edible* & Gills \\
\hline 8 & $\begin{array}{l}\text { Cantharellus } \\
\text { tomentosus }\end{array}$ & Cantharelaceae & Wipatwe & $\begin{array}{l}\text { Pale } \\
\text { yellow/ } \\
\text { brown }\end{array}$ & $\begin{array}{l}\text { Miombo } \\
\text { woodlands }\end{array}$ & Mycorrhizal & smooth & Inedible\# & Edible* & Gills \\
\hline 9 & $\begin{array}{l}\text { Cantharellus } \\
\text { densifolius }\end{array}$ & Cantharelaceae & Not known & Yellow & $\begin{array}{l}\text { Miombo } \\
\text { woodlands }\end{array}$ & Mycorrhizal & smooth & Inedible\# & Edible* & Gills \\
\hline 10 & $\begin{array}{l}\text { Afrocantharellus } \\
\text { symoensii }\end{array}$ & Cantharelaceae & Not known & Yellow & $\begin{array}{l}\text { Miombo } \\
\text { woodlands }\end{array}$ & Mycorrhizal & smooth & Inedible\# & Edible* & Gills \\
\hline 11 & Trametes menziesii & Polyporaceae & Wammabiki & $\begin{array}{l}\text { Cream } \\
\text { with } \\
\text { greenish } \\
\text { zones brown }\end{array}$ & $\begin{array}{l}\text { Miombo } \\
\text { woodlands }\end{array}$ & $\begin{array}{l}\text { Rotten dead } \\
\text { wood }\end{array}$ & Rough & Inedible & Inedible & Tubes \\
\hline 12 & $\begin{array}{l}\text { Pycnoporus } \\
\text { sanguineus }\end{array}$ & Polyporaceae & Wammabiki & $\begin{array}{l}\text { Bright } \\
\text { orange-red }\end{array}$ & $\begin{array}{l}\text { Miombo } \\
\text { woodlands }\end{array}$ & Dead wood & Smooth & Inedible & Inedible & Tubes \\
\hline
\end{tabular}




\begin{tabular}{|c|c|c|c|c|c|c|c|c|c|c|}
\hline Sn & $\begin{array}{l}\text { Wild Mushrooms } \\
\text { (scientific name) }\end{array}$ & Family name & $\begin{array}{l}\text { Vernacular } \\
\text { /local names } \\
\text { (Bennal } \\
\text { Hehe }) \\
\end{array}$ & $\begin{array}{l}\text { Cap } \\
\text { colour }\end{array}$ & $\begin{array}{l}\text { Ecological } \\
\text { classification }\end{array}$ & $\begin{array}{l}\text { Host or } \\
\text { substrate }\end{array}$ & $\begin{array}{l}\text { Cap } \\
\text { surface } \\
\text { texture }\end{array}$ & $\begin{array}{l}\text { Folk } \\
\text { taxonomy } \\
\text { (Edibility) }\end{array}$ & $\begin{array}{l}\text { Taxonomic } \\
\text { classification } \\
\text { (Edibility) }\end{array}$ & $\begin{array}{l}\text { Gills/tubes } \\
\text { and latex }\end{array}$ \\
\hline 13 & $\begin{array}{l}\text { Microporus } \\
\text { xanthopanus }\end{array}$ & Polyporaceae & Wammabikhi & Brown & $\begin{array}{l}\text { Miombo } \\
\text { woodlands }\end{array}$ & Tree stumps & Rough & Inedible & Inedible & Tubes \\
\hline 14 & Amanita muscaria & Amanitaceae & Mapaina & $\begin{array}{l}\text { Red with } \\
\text { white } \\
\text { flakes }\end{array}$ & $\begin{array}{l}\text { In pines } \\
\text { plantations }\end{array}$ & $\begin{array}{l}\text { In pines } \\
\text { mycorrhizal }\end{array}$ & $\begin{array}{l}\text { Smooth red } \\
\text { with white } \\
\text { spots }\end{array}$ & Inedible $\S$ & $\begin{array}{l}\text { Deadly } \\
\text { poisonous }\end{array}$ & Gills \\
\hline 15 & Amanita phalloides & Amanitaceae & Malingoti & $\begin{array}{l}\text { Pale } \\
\text { yellow to } \\
\text { olive-green }\end{array}$ & $\begin{array}{l}\text { In } \\
\text { Eucalyptus } \\
\text { plantations }\end{array}$ & $\begin{array}{l}\text { In } \\
\text { Eucalyptus } \\
\text { mycorrhizal }\end{array}$ & $\begin{array}{l}\text { Smooth and } \\
\text { slippery }\end{array}$ & Inedible $\S$ & $\begin{array}{l}\text { Deadly } \\
\text { poisonous }\end{array}$ & Gills \\
\hline 16 & $\begin{array}{l}\text { Chlorophyllum } \\
\text { molybdites }\end{array}$ & Agaricaceae & Not known & White & $\begin{array}{l}\text { Miombo } \\
\text { woodlands }\end{array}$ & Mycorrhizal & $\begin{array}{l}\text { Rough with } \\
\text { white } \\
\text { powdery } \\
\text { spots }\end{array}$ & Inedible & Inedible & Gills \\
\hline 17 & Suillus tomentosus & Suillaceae & Mamtima & Pale brown & $\begin{array}{l}\text { Miombo } \\
\text { woodlands }\end{array}$ & Mycorrhizal & Rough & Inedible & Inedible & Tubes \\
\hline 18 & & & & & & & & & & \\
\hline 19 & Suillus spp-1 & Suillaceae & Mamtima kijivu & Purple & $\begin{array}{l}\text { Miombo } \\
\text { woodlands }\end{array}$ & Mycorrhizal & Smooth & Inedible & Not known* & Tubes \\
\hline 20 & $\begin{array}{l}\text { Boletus } \\
\text { spectabilissimus }\end{array}$ & Boletaceae & $\begin{array}{l}\text { Ngamtima } \\
\text { mwekundu }\end{array}$ & $\begin{array}{l}\text { Reddish } \\
\text { yellow }\end{array}$ & $\begin{array}{l}\text { Miombo } \\
\text { woodlands }\end{array}$ & Mycorrhizal & Rough & Inedible & Inedible & Tubes \\
\hline 21 & Boletus spp-1 & Boletaceae & Mamtima & $\begin{array}{l}\text { Reddish } \\
\text { brown }\end{array}$ & $\begin{array}{l}\text { Miombo } \\
\text { woodlands }\end{array}$ & Mycorrhizal & Smooth & Inedible & Inedible & Gills \\
\hline 22 & Boletus spp-2 & Boletaceae & Not known & Brown & $\begin{array}{l}\text { Miombo } \\
\text { woodlands }\end{array}$ & Mycorrhizal & Smooth & Inedible & Not known* & Tubes \\
\hline 23 & Boletus spp-3 & Boletaceae & Mamtima kijivu & Purple & $\begin{array}{l}\text { Miombo } \\
\text { woodlands }\end{array}$ & Mycorrhizal & Smooth & Inedible & Inedible & Tubes \\
\hline 24 & Boletus spp-4 & Boletaceae & Ngamtima & $\begin{array}{l}\text { Reddish } \\
\text { yellow }\end{array}$ & $\begin{array}{l}\text { Miombo } \\
\text { woodlands }\end{array}$ & Mycorrhizal & Rough & Inedible & Inedible & Tubes \\
\hline
\end{tabular}

A questionnaire survey was used to collect preliminary information on wild mushrooms' edibility in the Njombe and Iringa regions which was further confirmed by conventional characterization. (*): Edible or of unknown edibility (Conventional); (\#): Inedible (folk); Edible (Conventional); ( $)$ : Inedible (folk); deadly poisonous (Conventional) 

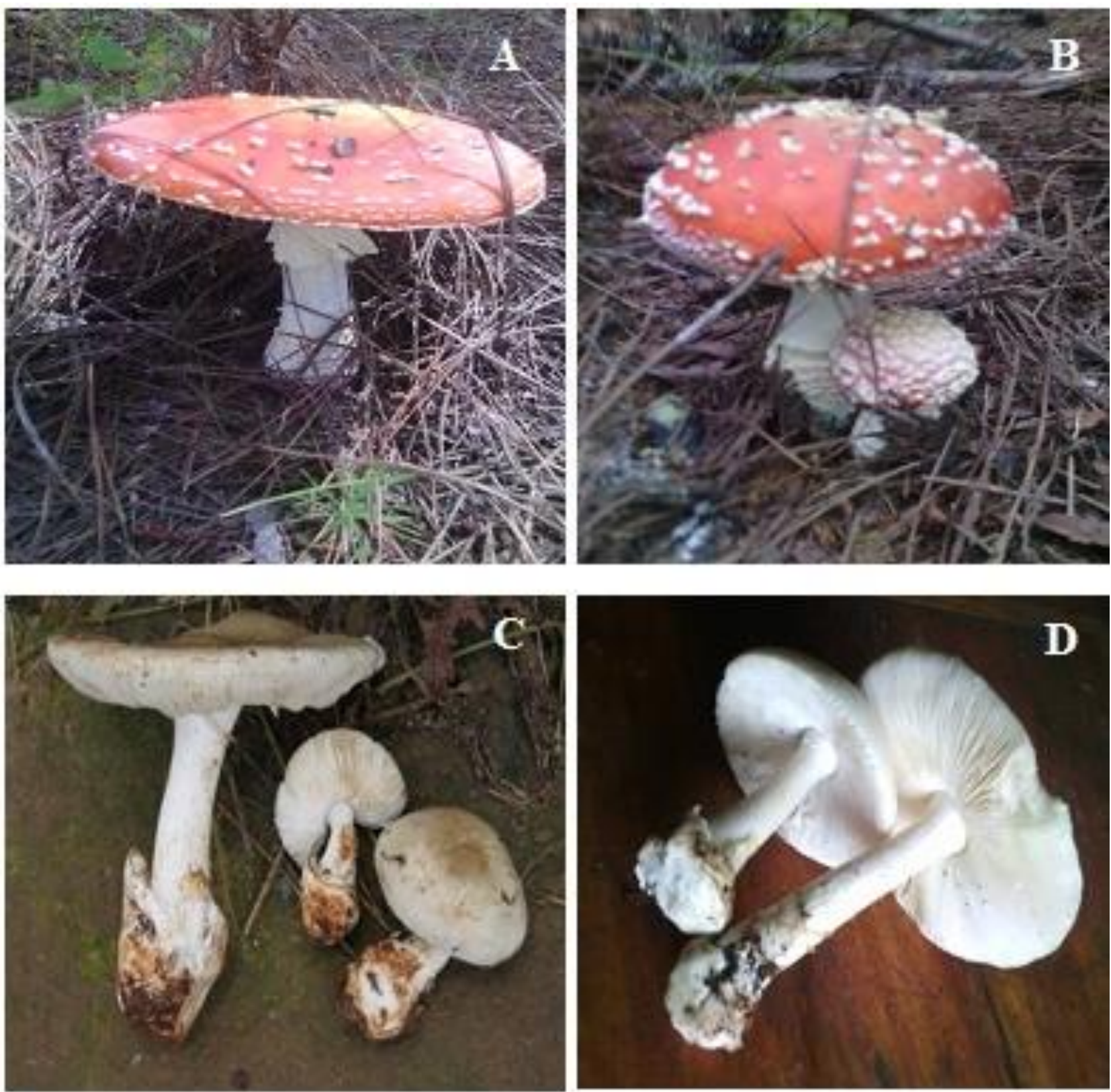

Fig. 3 - Deadly poisonous wild mushrooms in Amanitaceae family. A-B: Amanita muscaria; C-D: Amanita phalloides.

Amanita muscaria 'Mapaina' and Amanita phalloides 'Malingoti' were characterized as deadly poisonous wild mushrooms through conventional characterization (Fig. 3 \& Table 1). These poisonous species are from the Amanitaceae family. The commonly reported poisonous species in this group includes Amanita phalloides and other Amanita spp. (Konno 1997). Since there is no relationship between the edibility or toxicity of mushrooms and their appearance, colour, or any other characteristic whatsoever, poisonous mushrooms have bright, beautiful, or peculiar colours (Konno 1997). Only conventional taxonomy can easily distinguish deadly poisonous species from edible ones. Through indigenous taxonomy, the species were characterized as inedible without further information on their toxicity (Table 1). Other edible Amanita species of A. loosi, A. mafingensis, A. tanzanica, and A. masasiensis have also been reported in the Southern Highlands of Tanzania (Tibuhwa 2013, Chelela et al. 2014d).

On the other hand, 4 wild mushrooms of unknown edibility were also reported Table 1 \& Fig. 4) prompting further studies to establish their edibility. 

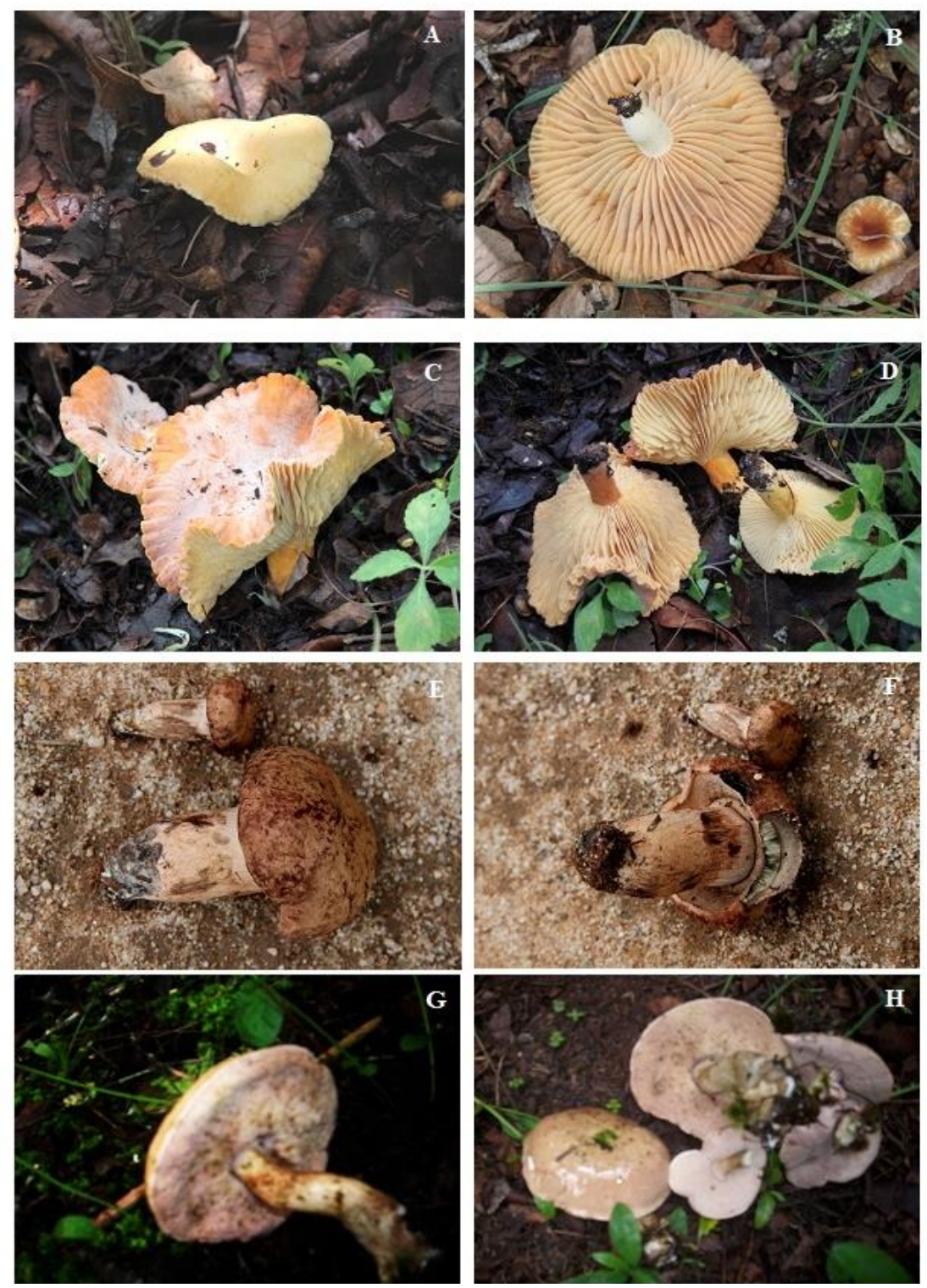

Fig. 4 - Mushroom species of unknown edibility in Russulaceae-2, Boletaceae-1 and Suillaceae-1, families. A-B: Lactarius spp-1; C-D: Lactarius gymnocarpoides; E-F: Boletus spp-2 and G-H: Suilluis spp-1.

Wild mushroom hunting and collection has been shown to contribute to food and nutritional security, alternative employment, forest conservation, and thus boosting the rural economy (Tibuhwa 2013) as well as improving livelihoods in rural communities in the Southern Highlands of Tanzania (Chelela et al. 2014d).

In summary, since wild mushrooms are naturally abundant resource in most places in Tanzania, proper characterization is necessary to further improve its utilization in the rural communities. Steps should be taken to build capacity of folk taxonomists including documentation of edible, inedible and poisonous species found in their areas. Conventional characterization has proven to be more reliable in distinguishing species of wild mushrooms with sufficient precision to avoid the accidental misidentification which may occur through the use of indigenous methods. Moreover, the rich biodiversity of wild mushrooms in Tanzania is only sparsely recorded. This is a potential source of increased food and nutritional security for the rural communities but only if appropriate characterization methods are utilized. Their wide geographical distribution, combined with the possibility of identifying new species, further justifies the importance of taxonomic characterization and documentation of edible and inedible wild mushroom species in Tanzania. 


\section{Conclusion}

In the present study, 7 edible, 11 inedible, and 2 deadly poisonous mushroom species were reported as well as 4 of unknown edibility. Conventional characterization further contributed to the indigenous knowledge through identifying more edible species. Misidentification of wild mushrooms may result in under exploitation of species with useful potential, in addition to fatalities resulting from consumption of poisonous species. Besides, inedible mushroom species should further be considered as a potential source of bioactive or medicinal compounds. Therefore, knowledge about the accurate characterization of wild mushroom species is necessary. More scientific studies are needed to establish the edibility of the wild mushroom species of unknown edibility in order to ensure the safety of consumers. Further exploitation of highly underutilized wild mushroom species as potential resources for food, bioactive compounds, and medicinal properties is of importance. Also, studies on characterization of wild mushrooms depending on seasonality and location are highly recommended.

\section{Acknowledgements}

The financial support from the Commission for Science and Technology (COSTECH) through the Nelson Mandela Africa Institute of Science and Technology is highly acknowledged. The authors are also grateful to the Department of Molecular Biology and Biotechnology-UDSM, for taxonomic characterization of wild mushrooms. The authors are grateful to the Benna and Hehe communities in the Southern Highlands of Tanzania for their contribution to this study. The authors would like to thank Prof. Tarimo Mokiti for his comments also, Dr. Carolyn Lyle and Dr. Anasia Maleko for revising the manuscript.

\section{References}

Abdalla RRM, Ahmed AI, Abdalla AI, Abdelmaboud OAA, Khiery NTMA, Elriah NDA, Saeed MSA. 2014 - Wild edible and medicinal mushroom species of Sudan. In Manjit OP, Upadhyay S, Sharma RC, Ahlawat VP, Satish MK, Kamal S, Arora B, Gupta, eds. 8th International Conference on Mushroom Biology and Mushroom Products, 19 - 22 November, 2014. New Delhi, India. Yugantar Prakashan Pvt. Ltd., WH-23 Mayapuri Industrial Area, Phase-I, New Delhi, 6.

Bloesch U, Mbago, F. 2008 - The potential of wild edible mushrooms in the miombo woodlands of the Selous-Niassa Wildlife corridor for the livelihood improvement of the local population. The United Republic of Tanzania, Ministry of Natural Resources and Tourism, Wildlife Division. Mushroom Study in Co-operation with ADAP, (April),1-36.

Boa E. 2004 - Wild edible fungi: A global overview of their use and importance to people. Food and Agriculture Organization of the United Nation, $25-70$.

Buyck B. 2012 - One Neo- and Four Epitypifications for Cantharellus Species from Tropical African savannah woodlands One neo- and four epitypifications for Cantharellus species from tropical African savannah woodlands. Cryptogamie, Mycologie 33, 11-17.

Buyck B, Randrianjohany É, Eyssartier G. 2012 - Observations on Some Enigmatic Cantharellus (Cantharellales , Basidiomycota ) with Lilac-Violaceous Tints from Africa and Madagascar. Cryptogamie, Mycologie 33, 167-179.

CABI, 2015 - Dictionary of the Fungi. CABI Database. Available at: http://www.speciesfungorum.org/names/fundic.asp [Accessed June 10, 2015].

Chang S, Miles P. 1992 - Mushroom biology - A new discipline. Mycologist 6, 64-65.

Chelela BL, Chacha M, Matemu A. 2014a - Antibacterial and antifungal activities of selected wild mushrooms from Southern Highlands of Tanzania. American Journal of Research Communication 2, 58-68.

Chelela BL, Chacha M, Matemu A. 2014b - Cytotoxicity activity of some wild mushroom species from Southern Highlands of Tanzania. American Journal of Research Communication 2, 192 201. 
Chelela BL, Chacha M, Matemu A. 2014c - Larvicidal potential of wild mushroom extracts against Culex quinquefasciatus Say, Aedes aegypti and Anopheles gambiae Giles S . S. American Journal of Research Communication 2, 105-114.

Chelela BL, Chacha M, Matemu A. 2014d - Wild edible mushroom value chain for improved livelihoods in Southern Highlands of Tanzania. American Journal of Research Communication, 2(8), $1-14$.

Van Dijik H, Onguene NA, Kuyper TW. 2003 - Knowledge and Utilization of Edible Mushrooms by Local Populations of the Rain Forest of South Cameroon. Ambio 32, 19-23.

Tibuhwa D, Buyck B, Kivaisi A, Tibell L, 2008 - Cantharellus fistulosus sp. nov. from Tanzania. Cryptogamie, Mycologie 9, 129-135.

Feeney MJ, Dwyer J, Hasler-Lewis CM, Milner JA, Noakes M, Rowe S, Wach M, Beelamn RB, Caldwell J, Cantona MT, Castlebury LA, Chang ST, Cheskin LJ, Clemens R, Drescher G, Fulgon VL $3^{\text {rd }}$, Haytowiz DB, Hubbard VS, Law D, Myrdal Miller A, Minor B, Percival SS, Riscuta G, Schneeman B, Thornsbury S, Toner CD, Woteki CE, Wu D. 2014 - Mushrooms and Health Summit Proceedings. The Journal of Nutrition 144, 1128S-1136S.

Haerkoenen M, Saarimaki T, Mwasumbi L. 1993 - Tanzanian mushrooms and their uses. II: An edible species of Coprinus section Lanatuli. Karstenia 33, 51-59.

Harkonen M, 2002 - Mushroom Collecting in Tanzania and Hunan (Southern China): Inherited Wisdom and Folklore of Two Different Cultures. In Watling R, Frankland JC, Ainsworth, AM, ed. Tropical Mycology: Macromycetes. CABI Publishing, pp. 149-165.

Härkönen M, Mwasumbi L, Niemelä T. 2003 - Tanzanian Mushrooms: Edible, Harmful and Other Fungi, Botanical Museum, Finnish Museum of Natural History.

Härkönen M, Saarimäki T, Mwasumbi L. 1994 - Edible and poisonous mushrooms of Tanzania. African Journal of Mycology and Biotechnology 2, 99-123.

Härkönen M, Saarimäki T, Mwasumbi, L. 1995 - Edible mushrooms of Tanzania. Yliopistopaino.

Hawksworth DL. 2004 - Fungal diversity and its implications for genetic resource collections. In Studies in Mycology 50, 9-18.

Kim MY, Seguin P, Ahn JK, Kim JJ, Chun SC, Kim EH, Seo SH, Kang EY, Kim SL, Park YJ, Ro HM, Chung IM. 2008 - Phenolic compound concentration and antioxidant activities of edible and medicinal mushrooms from Korea. Journal of Agricultural and Food Chemistry 56, 72657270.

Kirk P, Ansell A. 1992 - Authors of fungal names: A list of authors of scientific names of fungi, with recommended standard forms of their names, including abbreviations. Index of Fungi Supplement. CAB International, Ferry Lane, UK.

Konno K. 1997 - Poisonous mushrooms. Food Reviews International 13, 471-487.

Yongabi K, Agho M, Martinez Carrera D. 2004 - Ethnomycological Studies on Wild Mushrooms in Cameroon, Central Africa. Micología Aplicada International 16, 34-36.

Ramírez-Anguiano AC, Santoyo S, Reglero G, Soler-Rivas C. 2007. Radical scavenging activities, endogenous oxidative enzymes and total phenols in edible mushrooms commonly consumed in Europe. Journal of the Science of Food and Agriculture 87, 2272-2278.

Tibuhwa DD, Savić S, Tibell L, Kivaisi AK. 2012 - Afrocantharellus gen. stat. nov. is part of a rich diversity of African Cantharellaceae. IMA Fungus 3, 25-38.

Tibuhwa DD. 2012a - Folk taxonomy and use of mushrooms in communities around Ngorongoro and Serengeti National Park, Tanzania. Journal of Ethnobiology and Ethnomedicine 8, 36-44.

Tibuhwa DD. 2011a - Morphology and taxonomy of Sarcoscypha ololosokwaniensis sp . nov .: A new Ascomycota species from Serengeti National Park-Tanzania. Journal of Yeast and Fungal Research 2, 1-6.

Tibuhwa DD. 2011b - Substrate specificity and phenology of macrofungi community at the University of Dar es Salaam main campus, Tanzania. Journal of Applied Biosciences 46, 3173-3184.

Tibuhwa DD. 2013 - Wild mushroom-an underutilized healthy food resource and income generator: experience from Tanzania rural areas. Journal of Ethnobiology and Ethnomedicine 9, 49. 
Tibuhwa DD, Kivaisi AK. 2010 - Utility of the Macro-Micromorphological Characteristics Used in Classifying the Species of. Tanzania Journal of Science 36, 31-45.

Verbeken A, Buyck B. 2002 - Diversity and Ecology of Tropical Ectomycorrhizal Fungi in Africa. In A. M. Watling, Roy, Frankland, J.C., and Ainsworth, ed. Tropical Mycology: Macromycetes. Wallingford, Oxon, GBR: CABI Publishing, pp. 11-24.

Wong JY, Chye FY. 2009 - Antioxidant properties of selected tropical wild edible mushrooms. Journal of Food Composition and Analysis 22, 269-277. 